[RADIOCARBON, Vol 30, No. 3, 1988, P 297-317]

\title{
HARWELL RADIOCARBON MEASUREMENTS VI
}

\author{
A J WALKER and R L OTLET \\ Isotope Measurements Laboratory, Harwell Laboratory, \\ Oxfordshire, OX11 0RA, UK
}

\section{INTRODUCTION}

This is the first of a series of new lists of English archaeological dates commissioned for measurement by the Historic Buildings and Monuments Commission within prescribed contractual periods. This list, containing 121 dates, refers to the measurement period, April 1985 to March 1986, and results are reported irrespective of whether the associated projects are completed or ongoing.

All three measuring systems of the Isotope Measurements Laboratory were used-standard liquid scintillation counting (Otlet \& Warchal, 1978) to a precision of $\pm 1 \%$, miniature gas proportional counting (Otlet et al, 1983, Otlet, Huxtable \& Sanderson, 1986), and the larger sample, higher precision $( \pm 0.5 \%)$ liquid scintillation system brought into operation in 1985. In all cases, the error term quoted is the 1 sigma standard deviation estimate of the full replicate sample reproducibility (Otlet, 1979). Following further software developments, the basic text of the reports is now routinely prepared automatically from database entries using an in-house microcomputer and no longer requires a mainframe.

Calculations are based on the Libby half-life of 5568 years, using NBS oxalic acid standard $(\times 0.95)$ as "modern," both values treated as constants with AD 1950 as the reference year. All results are corrected for fractionation according to the quoted $\delta^{13} \mathrm{C}$ (wrt PDB) values measured in this laboratory.

\section{ACKNOWLEDGMENTS}

We wish to acknowledge the work of our colleagues D G Humphreys, M M Gibson, and S M Dadson with the laboratory measurements and S E Hasler and J Conlon with the preparation of the data. The financial support of the Historic Buildings and Monuments Commission which funded both the sample measurements and this publication and the cooperation of the staff of the Ancient Monuments Laboratory is also gratefully acknowledged.

\section{ARCHAEOLOGIC SAMPLES}

$$
\text { England }
$$

\section{Thirlings series}

Four charcoal samples taken from different features at Thirlings,

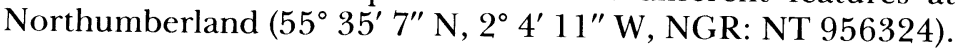


HAR-1450. F71

Ca 20\% id. as hawthorn type (Crataegus/Pyrus/Sorbus/Malus sp), hazel (Corylus avellana L) and probably cf blackthorn (Prunus sp), AML 757514, from late Neolithic pit containing pottery, organic material, and saddle quern. Coll and subm Dec 1975 by R Miket, Arbeia Roman Fort and Museum.

HAR-6240. $\quad$ I1467

$2060 \pm 150$

AML 850836, from post hole of building foundation. Coll and subm Jan 1984 by C. F O'Brien, Univ Newcastle-upon-Tyne.

HAR-6658. F72

$4450 \pm 100$ $\delta^{13} C=-26.1 \% 0$

Ca $50 \%$ id. by C A Keepax as hawthorn, hazel, from fairly large branches and timbers, AML 757515, from pit containing bucket-shaped vessel. Subm Dec 1975 By R Miket.

HAR-6659. F25

$4530 \pm 130$

$\delta^{13} C=-26.4 \%$

AML 757517, from circular timber structure within settlement. Subm Dec 1975 by R Miket.

\section{HAR-1923. HA76AV}

$$
\begin{array}{r}
3460 \pm 140 \\
\delta^{13} C=-26.7 \% 0
\end{array}
$$

Charcoal, id. by C A Keepax as mainly willow/poplar from large timbers plus cf blackthorn and gorse/broom both mainly twiggy, from deposit of burned material, including sand, on bedrock floor of circular building at Harlyn Bay Iron Age Cemetery, North Cornwall. Coll and subm Sept 1976 by R P Whimster, Royal Comm Historical Monuments of England. Comment (RPW): sample came from excavation of occupation layers antedating use of area for burial and apparently belongs to final destruction phase of building (Whimster, 1977).

\section{Mucking series}

\section{HAR-2337. 21958996}

Wood, carbonized twig, AML 776299, from pit partly obliterated by Saxon sunken hut at Mucking, Essex (51 $29^{\prime} 47^{\prime \prime}$ N, $0^{\circ} 24^{\prime} 38^{\prime \prime}$ E, NGR: TQ $673803)$. Coll and subm May 1977 by M U Jones.

HAR-2651. R17-1476

$2440 \pm 100$

$\delta^{13} \mathrm{C}=-23.0 \%$

Animal bone, AML 7716309, from Feature 5JJ, Layer 7063, primary silt of Early Iron Age enclosure ditch at MARC 3 R1 7, Winnall Down. Coll 
and subm May 1977 by P J Fasham, Trust for Wessex Archaeol. Comment (PJF): assoc with hematite-coated pottery. Other dates are included in site report (Fasham, 1985).

\section{MVW79-4611 series}

HAR-3521. SLP7917

$$
\begin{array}{r}
2830 \pm 100 \\
\delta^{13} C=-25.2 \%
\end{array}
$$

Soil, AML 794484, from charred plant beneath stone slab on central hearth, N mound at Meare Village West, Somerset $\left(51^{\circ} 10^{\prime} 33^{\prime \prime} \mathrm{N}, 2^{\circ} 47^{\prime} 38^{\prime \prime}\right.$ W, Natl Grid Ref ST 445422). Coll and subm Sept 1979 by J M Coles, Somerset Levels Project. Comment ( JMC): dating material from this context was sparse; this date varies with others from comparable strata yielding dates from 2050 to 2250 BP (Orme et al, 1981).

\section{HAR-4490. HYMD781}

$$
\begin{array}{r}
\mathbf{2 8 2 0} \pm \mathbf{8 0} \\
\delta^{13} C=-25.7 \% 0
\end{array}
$$

Charcoal, id. as oak and ash, from beneath bank around Iron Age enclosure at Mingie's Ditch, Hardwick, Oxon (51 $45^{\prime} 00^{\prime \prime} \mathrm{N}, 1^{\circ} 26^{\prime} 01^{\prime \prime} \mathrm{W}$, Natl Grid Ref SP 391059). Coll and subm May 1981 by M Robinson, Oxford Univ Mus. Comment (MR): this charcoal layer probably resulted from late Bronze Age clearance, also represented on site by tree-clearance pit dated to $2800 \pm 90 \mathrm{BP}(\mathrm{HAR}-4489)$.

\section{Wharram Percy series}

Samples from Site 30, Wharram Percy, North Yorkshire. All samples coll and subm by J G Hurst, Historic Buildings and Monuments Commission, London.

HAR-4649. 30/1640A

$1080 \pm 100$

Bone, AML 812982, from below carbonized grain layer. Coll and subm Aug 1981. Comment (JGH): sample came from bottom-most excavated layer.

HAR-4650. 30/1640B

$1060 \pm 100$

Bone, AML 812983, from below carbonized grain layer (?Middle Saxon). Coll and subm Aug 1981. Comment (JGH): sample came from bottom-most excavated layer.

\section{HAR-4652. $30 / 1642$}

$750 \pm 90$

Wood, AML 812985, part of line of wattle, possibly part of lowest down feature on site. Coll and subm Aug 1981. Comment (JGH): sample from different line of wattle from 30/1641 (HAR-4651) dated to $860 \pm$ 70 . 
HAR-5624. 59/149

$$
\begin{array}{r}
1120 \pm 100 \\
\delta^{13} C=-26.7 \%
\end{array}
$$

Charcoal, AML 826043, from fill of small bowl-shaped hearth of Saxon smithy. Subm June 1983. Comment (JGH): hearth was well-defined cut feature, probably of short life, and is one of three assoc within timber post-built structure. Whole complex is very similar to that at Ramsbury (Wiltshire). Assoc pottery suggests early-mid-Saxon date.

HAR-6787. 1569/120

$$
\delta^{13} C=\begin{array}{r}
\mathbf{6 6 0} \pm \mathbf{9 0} \\
-25.5 \% 0
\end{array}
$$

Wood, AML 811624A, from unid. item at base of waterlogged silt deposits. Coll and subm Aug 1981.

\section{Lincoln series}

One of series of samples from single-celled church or chapel at St Paulin-the-Bail, Lincoln, coll and subm July 1982 by B Gilmour, Lincoln Archaeol Trust.

HAR-5098. 33BQH533

$1730 \pm 110$

Human bone, AML 812976.

\section{Castle Farm series}

Charcoal from Iron Age Fort at Castle Farm Shifnal, Shropshire. Coll and subm Oct 1981 by A Roe, Birmingham Univ Field Archaeol Unit.

HAR-5116. CF802238

$3810 \pm 110$

$\delta^{13} \mathrm{C}=-27.2 \%$

AML 815098, from clay layer, possibly first disuse phase of Late Iron Age or Roman inner ditch (F100).

HAR-5118. CF808007

$$
\begin{array}{r}
\mathbf{2 2 9 0} \pm \mathbf{1 0 0} \\
\delta^{13} C=-27.2 \% 0
\end{array}
$$

AML 815103, from gray sandy layer producing VCP pottery within feature (F800) on Site L, E side of enclosure.

HAR-5279. 230-41

$730 \pm 140$

$$
\delta^{13} \mathrm{C}=-25.0 \%
$$

Charcoal, AML 8210221, from old land surface beneath bank around probable Dark Age Burgh at Daws Castle, Watchet, Somerset. Coll and subm Nov 1982 by N D Balaam, Ancient Monuments Lab, London.

\section{Trelan series}

Charcoal from Bronze Age barrow site, Trelan 2, subm by N D Balaam.

HAR-5280. 41-062

$$
\begin{array}{r}
\mathbf{3 8 9 0} \pm \mathbf{1 2 0} \\
\delta^{13} \mathrm{C}=-26.9 \%
\end{array}
$$

AML 8110749 , from stakehole beneath barrow. Coll June 1981 by G Smith and subm Nov 1982. 
HAR-5510. 41-062

AML 8110716, from primary fill of first phase ditch of barrow. Coll June 1981 by G Smith and subm March 1983.

\section{Claydon Pike series}

One of series of bone and charcoal samples from Claydon Pike, Gloucestershire. Coll and subm Jan 1983 by D Miles, Oxford Archaeol Unit.

\section{HAR-5407. FCP1}

$2380 \pm 120$

Animal bone from low levels of enclosure ditch. Comment (DM): on pottery evidence, enclosure ditch is Late Iron Age.

\section{Rough Ground Farm series}

Bone from Rough Ground Farm, Lechlade, Gloucestershire. Coll and subm March 1983 by T G Allen, Oxford Archaeol Unit.

HAR-5498. RGF784

From grooved-ware rubbish pit.

HAR-5499. RGF1260

From domestic rubbish pit, Beaker culture.

HAR-5505. RGF1280

From basal fill of early Iron Age pit.
$4100+100$

$\delta^{13} C=-23.8 \%$

$3710 \pm 100$

$\delta^{13} C=-22.6 \%$

$1760 \pm 100$

$\delta^{13} C=-23.9 \%$

\section{Cowleaze series}

Charcoal from bowl barrow at Cowleaze, Winterbourne Stepleton, Dorset $\left(50^{\circ} 41^{\prime} 55^{\prime \prime} \mathrm{N}, 2^{\circ} 32^{\prime} 54^{\prime \prime} \mathrm{W}\right.$, Natl Grid Ref SY 61288898). Coll and subm June 1983 by P J Woodward, Trust for Wessex Archaeol. For full details of site, see Woodward (1988).

\section{HAR-5617. 968}

$$
\begin{array}{r}
3390 \pm 100 \\
\delta^{13} C=-24.5 \% \text { o }
\end{array}
$$

Id. as Quercus sp, AML 831127, from clay-enriched soil at base of accumulated soil profile in barrow ditch (850). Comment (PJW): date must be compared with further samples from this soil development profile in barrow ditch; result is of right order and compares with construction data for neighboring enclosure (HAR-5622, $3410 \pm 80$ ).

HAR-5620. 1281

$$
\begin{array}{r}
3140 \pm 130 \\
\delta^{13} C=-26.3 \% 0
\end{array}
$$

Id. as Quercus and Carpinus spp, AML 831132, from Cremation 2 assoc with jet toggle and bronze awl. 
HAR-5623. 1150

Id. as Pomoideae, AML 831136, from primary fill of field/cemetery boundary.

\section{Westward Ho series}

Samples from Westward Ho, North Devon coll and subm by N D Balaam.

HAR-5632. 8311026

$\mathbf{6 5 8 0} \pm \mathbf{1 5 0}$
$\delta^{13} C=-27.1 \%$

Charcoal, AML 8311026, from upper levels of Mesolithic midden. Subm June 1983.

HAR-6513. 8311353

$$
\delta^{13} C=-24.6 \%
$$

Animal bone, AML 8311353, from extensive midden-like deposit contained within silted-up estuarine channels. Subm March 1985. Comment (NDB): size of bones of some of domesticates suggests late prehistoric/ Romano-British date.

\section{Manor Farm, Borwick series}

Bone samples from Bronze Age burial monument at Manor Farm, Borwick, Lancashire $\left(54^{\circ} 08^{\prime} 45^{\prime \prime} \mathrm{N}, 2^{\circ} 44^{\prime} 44^{\prime \prime} \mathrm{W}\right.$, Natl Grid Ref SD 513725). Coll and subm by A C H Olivier, Dept Archaeol, Univ Lancaster, July 1983. For details of site, see Olivier (1983).

HAR-5659. MF82SF52

$$
\begin{array}{r}
\mathbf{2 5 8 0} \pm \mathbf{1 1 0} \\
\delta^{13} C=-22.4 \%
\end{array}
$$

Scatter of human bone, AML 831223, recovered during removal of main cairn (002) which overlay limestone enclosure. Comment (ACHO): result indicates possible Iron Age re-use of monument.

HAR-5661. MF82SF55B

$3450 \pm 70$

$\delta^{13} C=-21.0 \%$

Animal bone, AML 831792, id. as cat, from amongst human bone of central inhumation (HAR-5658, $3270 \pm 80 \mathrm{BP})$.

\section{Lizard series}

HAR-5668. 235-220

$$
\begin{array}{r}
\mathbf{5 4 7 0} \pm \mathbf{1 3 0} \\
\delta^{13} C=-24.5 \% 0
\end{array}
$$

Charcoal, id. as mainly Quercus sp, AML 8211180 , from charcoal-rich Mesolithic feature at Windmill Farm, Lizard, Cornwall. Coll and subm July 1983. 
Ardleigh series

Charcoal from cremations in Bronze Age cemetery at Ardleigh, Essex $\left(51^{\circ} 54^{\prime} 34^{\prime \prime} \mathrm{N}, 0^{\circ} 59^{\prime} 1^{\prime \prime} \mathrm{E}\right.$, Natl Grid Ref TM 052277). Coll and subm Sept 1983 by N D Balaam.

HAR-5744. 29-7249

$$
2880 \pm 70
$$

Id. by N D Balaam as Alnus glutinosa, mature wood, AML 8319351, from cremation.

HAR-5745. 29-7270

$2810 \pm 120$

AML 8319352.

General Comment (NDB): results help establish date of cemetery.

\section{Bantham Ham series}

Two samples from same context, suggested post-Roman hearth, at Bantham Ham, Devon $\left(50^{\circ} 16^{\prime} 35^{\prime \prime} \mathrm{N}, 3^{\circ} 52^{\prime} 38^{\prime \prime} \mathrm{W}\right.$, Natl Grid Ref SX 66254357). Subm Oct 1983 by Frances Griffith, Devon County Council.

HAR-5775. BANTH02

Bone.

HAR-5776. BANTH01

Charcoal, AML 823530.

HAR-6136. A6F125A Sept 1983 by S P Needham.

\section{Cannington series}

One of series of human bone samples from cemetery at Cannington, Somerset. Coll and subm Aug 1984 by S M Hirst and S M Wright.

HAR-6259. 374

$$
\begin{array}{r}
1680 \pm 130 \\
\delta^{13} C=-22.6 \% \text { o }
\end{array}
$$

AML 841014, from grave assoc with slab-marked grave mound. Comment (SMW): grave is on N periphery of main concentration of graves, is later than path (FT 23), and is potentially one of latest graves.

\section{Somerset Levels series}

Wood samples from 1984 and 1985 excavations at Somerset Levels site, Somerset. For more data on project, see Harwell II (Otlet, 1977, 
p 360-364), Harwell IV (Otlet \& Walker, 1979, p 77-80) and Harwell V (Walker, Keyzor \& Otlet, 1987, p 87-92).

\section{HAR-6263. SLP8402}

$$
3470 \pm 90
$$

Id. as oak, from plowed field at Fordgate, Sedgemoor $\left(51^{\circ} 4^{\prime} 54^{\prime \prime} \mathrm{N}, 2^{\circ}\right.$ 58' 32" W, Natl Grid Ref ST 31673187). Coll and subm Aug 1984 by J M Coles, Somerset Levels Project. Comment (JMC): plowed field in area undergoing drainage and cultivation has yielded various prehistoric surface finds. Oak trunk used for this sample was 1 of 6 from same source used for tree-ring studies and chronology building. Original context and approximate date was unknown. Actual sample dated came from outermost 50 sapwood rings of tree ca 160 years old (O'Hare, 1985).

\section{HAR-6606. SLP8501}

$$
\begin{array}{r}
\mathbf{3 2 2 0} \pm \mathbf{8 0} \\
\delta^{13} C=-29.0 \%
\end{array}
$$

AML 852173, from area assoc directly with foundation deposit of Bronze Age trackway, in peats closely linked to flooding horizon at Meare Heath (51 $09^{\prime} 31^{\prime \prime} \mathrm{N}, 2^{\circ} 47^{\prime} 48^{\prime \prime} \mathrm{W}$, Natl Grid Ref ST 443403). Coll April 1985 by A G Brown, subm April 1985 by J M Coles, Somerset Levels Project.

\section{HAR-6607. SLP8502}

$$
\begin{array}{r}
\mathbf{3 1 2 0} \pm \mathbf{8 0} \\
\delta^{13} C=-29.0^{0} \%
\end{array}
$$

AML 852174, from same context as HAR-6606.

\section{Haseley Manor series}

One of series of samples from cores taken from features of multiperiod building, Haseley Manor, Arreton, Isle of Wight. Samples coll and subm by D Haddon-Reece, Ancient Monuments Lab, London.

\section{HAR-6353. HM83H}

$580 \pm 100$

Wood, id as oak (Quercus sp) by D Haddon-Reece, AML 841018 , from $\mathrm{N}$ arch brace. Comment (DHR): one end is outer face of beam. Sample taken to date arch-braced collar truss which is included in earliest discernible part of building.

\section{Beeston Castle series}

All charcoal samples id. as oak (Quercus sp) from Beeston Castle, Bunbury, Cheshire (53 $7^{\prime} 43^{\prime \prime} \mathrm{N}, 2^{\circ} 41^{\prime} 26^{\prime \prime} \mathrm{W}$, Natl Grid Ref SJ 538593). Coll and subm July 1984 by P Hough.

\section{HAR-6459. BC0323}

$$
\begin{array}{r}
\mathbf{2 4 9 0} \pm \mathbf{1 0 0} \\
\delta^{13} C=-27.7 \% \text { o }
\end{array}
$$

AML 834993, from beneath one of series of very large boulders which collapsed out of early phase of rampart to seal latest pre-castle road surface. Comment $(\mathrm{PH})$ : sample dates sealing of final phase of prehistoric castle road system. 
HAR-6462. BC0546

$\mathbf{5 1 4 0} \pm \mathbf{9 0}$

$\delta^{13} C=-27.8 \%$

AML 834997, from lowest fill of earliest cut of $\mathrm{N}$ prehistoric ditch, sealed in part by colluvial sands.

HAR-6464. BC0621/D

$2300 \pm 80$ ple contains 40 to 50 rings.

HAR-6468. BC0621/B

$2290 \pm 70$

AML 834991, from timbers of rampart. Comment $(\mathrm{PH})$ : sample contains 20 to 30 rings of small diameter and probably represents most of radius of young tree.

HAR-6469. BC0621/C

$\mathbf{2 3 7 0} \pm \mathbf{8 0}$
$\delta^{13} C=-24.4 \%$

AML 834992, from timbers of rampart. Comment (PH): sample contains many rings.

HAR-6503. BC0621/Q

$$
\begin{array}{r}
2350 \pm 70 \\
\delta^{13} C=-26.0 \% 0
\end{array}
$$

AML 834977, from structural timber of rampart. Comment (PH): sample contains ca 40 rings and comes from mature tree.

HAR-6504. BC0234

$$
2310 \pm 70
$$$$
\delta^{13} C=-25.3 \%
$$

AML 834996, sample sealed into roadway leading into hill-fort entrance. Comment $(\mathrm{PH})$ : roadway seals ditch from which Sample 86 (HAR$6462,5140 \pm 90$ ) was taken. Material is possibly result of site clearance.

\section{Barton-on-Humber series}

Wood samples from St Peter's Church, Barton-on-Humber, Humberside (53 $40^{\circ} 59^{\prime \prime} \mathrm{N}, 0^{\circ} 25^{\prime} 58^{\prime \prime} \mathrm{W}$, Natl Grid Ref TA 035219). Coll July 1981 and subm July 1984 by W Rodwell. For details of site, see Rodwell and Rodwell (1982).

\section{HAR-6476. BH08}

$1010 \pm 80$

Id. as oak (Quercus sp), AML 841591, from lid of coffin F4181.

\section{HAR-6501. BH07}

$$
\begin{array}{r}
\mathbf{9 0 0} \pm \mathbf{7 0} \\
\delta^{13} C=-26.8 \% 0
\end{array}
$$

Id. as oak (Quercus sp), AML 841275, from part of coffin (F3564), shaped in dug-out manner. Comment (WR): sample contains ca 7 rings of 
average width (ca $3 \mathrm{~mm}$ ), from curvature of sample and coffin's construction. It is possible that rings were near outside of tree.

HAR-6838. BH09

$$
\begin{array}{r}
900 \pm 100 \\
\delta^{13} C=-28.1 \% 0
\end{array}
$$

Id. by Jacqui Watson as Salix/Populus sp, AML 800554, from part of wicker basket handle found in putlog hole on inside of tower wall. Comment (WR): basket presumed contemporary with building of tower.

\section{Drayton Cursus series}

Bone from Drayton Cursus, Abingdon, Oxfordshire. Subm Aug 1984 by R Chambers, Oxford Archaeol Unit.

HAR-6477. ABDC821

HAR-6478. ABDC822

$$
\begin{array}{r}
4990 \pm 100 \\
4780 \pm 100 \\
\delta^{13} C=-19.0 \%
\end{array}
$$

\section{Wenlock Priory series}

Bone samples from Wenlock Priory, Much Wenlock, Shropshire $\left(52^{\circ}\right.$ $35^{\prime} 49^{\prime \prime} \mathrm{N}, 2^{\circ} 33^{\prime} 13^{\prime \prime}$ W, Natl Grid Ref SJ 625001), coll June 1982 and subm July 1982 by H Woods.

HAR-6496. 822562

$1290 \pm 70$

Animal bone, AML 822562, from midden layer 62 into which burials are cut and which is sealed by early Medieval layer 56 . Layer 62 overlies and layer 69 contains alluvial silt which was limit of excavation. Layer 62 was earliest deposit on site.

HAR-6553. 53822545

$\mathbf{9 5 0} \pm 80$

$\delta^{13} C=-23.5 \%$

Human bone, AML 822545, from burial 53, sealed by ground surface 48 which cuts ground surface 56 and burials 57 and 58 .

HAR-6554. 59822548

$890 \pm 70$

Human bone, AML 822548, from burial 59, sealed by ground surface 48 , cutting ground surface 56 , but cut by burial 57 .

HAR-6555. 58822547

$890 \pm 80$

Human bone, AML 822547, from burial 58 , sealed by ground surface 48 , cutting ground surface 56 , but cut by burial 53 . Wooden base of coffin rests on midden layer 62 .

HAR-6556. 68822549

$$
\begin{array}{r}
\mathbf{9 6 0} \pm \mathbf{8 9 0} \\
\delta^{13} C=-23.7 \% 0
\end{array}
$$

Human bone, AML 822549, from burial 68 , which is cut by construction trench 51 for wall 63 , and which cuts into wall 52 and layers 62,66 , and 69 . 
HAR-6609. 57822546

Human bone, AML 822546 , from burial 57 , sealed by ground surface 48 , cutting ground surface 56 and burial 59 , but cut by burial 53 .

General Comment: ${ }^{14} \mathrm{C}$ results were intended to date stratigraphically closely related sequence of burials 53 (latest), 57, 58, 59, and 68 (earliest). However, dates obtained show that time span for whole sequence was small and thus, it is not possible to differentiate between phases. Layer 62 (HAR6496) was earliest at site and burial sequence provides terminus for this (Wood, 1987).

\section{HAR-6497. SL835AJ}

$$
\begin{array}{r}
\mathbf{2 2 8 0} \pm \mathbf{8 0} \\
\delta^{13} C=-28.5 \% 0
\end{array}
$$

Wood, id. as Populus sp (Poplar) by D Haddon-Reece, AML 840002, from base of waterlogged ditch at Swarkestone Lows, Parish of Swarkestone, Derbyshire (52 $51^{\prime} 41^{\prime \prime} \mathrm{N}, 1^{\circ} 27^{\prime} 17^{\prime \prime} \mathrm{W}$, Natl Grid Ref SK 367295). Coll and subm Dec 1983 by S Losco-Bradley, Trent and Peak Archaeol Trust. For descriptions of site, see Greenfield $(1956,1960)$ and Posnansky (1956).

\section{HAR-6498. SCK}

$$
\begin{array}{r}
\mathbf{8 2 1 0} \pm \mathbf{1 5 0} \\
\delta^{13} C=-30.8 \% 0
\end{array}
$$

Wood, id. as Salix/Populus sp by J Watson, AML 832976, possibly only surviving remnant of late Mesolithic arrow shaft, found embedded in peat

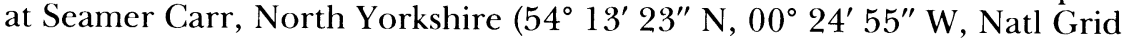
Ref TA 033820). Coll and subm Nov 1984 by A David, Historic Buildings and Monuments Comm, London. Comment (AD): sample was one of series of dates from Seamer Carr project; peat in which wood was embedded was previously dated to $8020 \pm 90 \mathrm{BP}(\mathrm{HAR}-5789)$.

\section{HAR-6500. BLF/01/0014}

$$
\begin{array}{r}
\mathbf{7 1 7 0} \pm \mathbf{8 0} \\
\delta^{13} C=-26.8 \% 0
\end{array}
$$

Charcoal from soft dark brown soil lying on base of bowl-shaped pit, but probably not burned in situ. Upper part of pit was filled with brown clay and stone material. Charcoal was found 0.5 to $0.6 \mathrm{~m}$ below modern turf at Lismore Fields, Buxton, Derbyshire (53 $15^{\prime} 17^{\prime \prime} \mathrm{N}, 1^{\circ} 55^{\prime} 30^{\prime \prime} \mathrm{W}$, Natl Grid Ref SK 050731). Coll Sept 1984 by P Losco-Bradley, subm Dec 1984 by G C Guilbert, Trent and Peak Archaeol Trust. Comment (GCG): sample defines chronology of broad late Mesolithic/Neolithic date indicated by flint work from 1984 trial excavation. 1985 excavations have shown discrete areas of Mesolithic and Neolithic occupation and structures.

\section{HAR-6505. N80/15}

$4130 \pm 120$

$$
\delta^{13} C=-25.3 \%
$$

Charred wood and hazelnut shells forming middle layer in fill of small feature (15), probably post hole, 1 of 9 forming roughly trapezoidal setting or structure at Newton Cliffs, Lincolnshire $\left(53^{\circ} 14^{\prime} 41^{\prime \prime} \mathrm{N}, 0^{\circ} 45^{\prime} 49^{\prime \prime} \mathrm{W}\right.$, Natl Grid Ref SK 825727). Coll and subm Aug 1983 by D Garton, Trent 
and Peak Archaeol Trust. Comment (DG): date was required to distinguish between two possible contexts for putative structure because pit (11), containing Late Beaker pottery and Mesolithic flint knapping area, coincided with posthole setting (Garton, 1983).

\section{Heslerton Parish series}

Four results from series of samples subm from multi-phase site at Heslerton Parish, Vale of Pickering $\left(54^{\circ} 10^{\prime} 33^{\prime \prime} \mathrm{N}, 0^{\circ} 35^{\prime} 42^{\prime \prime} \mathrm{W}\right.$, Natl Grid Ref SE 917765$)$. Site covers $80 \mathrm{~km}^{2}$ with evidence of activity from Neolithic to Anglian periods. Samples dated include all phases of site and are intended to establish fundamental chronology both for sites, themselves, and Eastern Yorkshire as a whole. All samples coll between 1977 and 1982 and subm Oct 1984 by D J Powlesland, Heslerton Parish Project.

\section{HAR-6516. HP00003C}

$$
1690 \pm 70
$$

Human bone, AML 841203, context 2B00055, from burial in pit alignment boundary of Anglian cemetery. Comments: $\delta^{13} \mathrm{C}$ measurement assumed (DP): iron object was apparently lodged in spine of skeleton.

\section{HAR-6517. HP00001C}

$2280 \pm 80$

Human bone, AML 841201, context 1A00018, from prone burial in Anglian cemetery, originally thought to be Late Saxon insertion into pagan cemetery.

\section{HAR-6519. HP00008C}

$$
1650 \pm 100
$$

Charcoal, AML 841208, from context 2R00012, from second SFB fill in Anglian settlement, $250 \mathrm{~m}$ to SW of site $2 \mathrm{M}$. Comment (DP): sample gives weight to hypothesis that cemetery and settlement are contemporary.

\section{HAR-6630. HP00016C}

$$
4060 \pm 80
$$

Human bone, AML 841216, from primary burial within Early Bronze Age barrow. Comments: $\delta^{13} \mathrm{C}$ measurement assumed (DP): bones in this burial were disturbed for insertion of secondary burial IR304, HAR-6631 $(3510 \pm 80)$.

\section{HAR-6690. HP00012C}

$$
\begin{array}{r}
\mathbf{3 8 4 0} \pm \mathbf{4 0} \\
\delta^{13} C=-26.4 \% o
\end{array}
$$

Charcoal, AML 841212, context 1L00034, from large deposit sealed by preserved barrow mound and adjacent to cremation burial $1 \mathrm{~L} 00065$ in Early Bronze Age barrow cemetery.

\section{Everley Water Meadow series}

Charcoal samples from Everley Water Meadow, Hambledon Hill, Dorset $\left(50^{\circ} 54^{\prime} 8^{\prime \prime} \mathrm{N}, 2^{\circ} 11^{\prime} 52^{\prime \prime} \mathrm{W}\right.$, Natl Grid Ref ST 86101151). Coll and subm Jan 1985 by R J Mercer, Univ Edinburgh. 


\section{HAR-6529. EWM8361}

$3160 \pm 70$

AML 850037, from trench 2, layer 1A, sec 2.

\section{HAR-6530. EWM84292}

AML 850038, from trench 3, layer 4, sec 6.

$3090 \pm 80$

HAR-6531. EWM84331

$3070 \pm 70$

$\delta^{13} C=-25.7 \%$

\section{Bromfield Quarry series}

Charcoal from Bromfield Quarry, Shropshire $\left(52^{\circ} 23^{\prime} 37^{\prime \prime} \mathrm{N}, 2^{\circ} 45^{\prime}\right.$ 35" W, NGR: SO 483776). Coll and subm Sept 1984 by S C Stanford. For description of site, see Stanford $(1980,1982)$.

\section{HAR-6544. S168}

$$
\begin{array}{r}
\mathbf{2 4 0 0} \pm \mathbf{8 0} \\
\delta^{13} C=-25.7 \% 0
\end{array}
$$

AML 841437, from post socket (F410), of single phase four post structure within single-ditched farm enclosure, but only $1.6 \mathrm{~m}$ from lip of ditch. Comment (SCS): result indicates open Iron Age settlement and gives terminus post quem for enclosure (E2). Pottery from this is dated Iron Age but enclosure could be Roman.

HAR-6545. S175

$$
\begin{array}{r}
\mathbf{2 1 3 0} \pm \mathbf{7 0} \\
\delta^{13} C=-25.3 \% 0
\end{array}
$$

AML 841438, from upper filling of shallow pit (F480). Comment (SCS): with HAR-6544 qv this result strengthens case for open Iron Age settlement preceding enclosure.

\section{HAR-6546. S182 and 183}

$$
\begin{array}{r}
1800 \pm 70 \\
\delta^{13} C=-25.9 \%
\end{array}
$$

AML 841439, from upper filling of enclosure (E2), ditch F401. Comment (SCS): sample should relate to extramural activities after abandonment of enclosure for which it provides terminus ante quem. With only $800 \mathrm{~mm}$ gravelly filling beneath, in ditch only $2 \mathrm{~m}$ wide at sample level, it must be unlikely that ditch was dug before first century AD.

\section{HAR-6547. S228 and 230}

$$
\begin{array}{r}
3460 \pm 90 \\
\delta^{13} C=-24.4 \% 0
\end{array}
$$

AML 841440, from well-preserved pyre base on old ground surface below few centimeters of preserved barrow material. Charcoal layer of pyre was cut by primary grave F266. Comment (SCS): sample dates barrow B15 within Bromfield funerary sequence and provides terminus ante quem for preceding Beaker use of site. 
HAR-6560. S231

AML 841441, from primary cremation grave F266 in center of barrow B15, below barrow turf but cut through pyre layer. Comment (SCS): result supports HAR-6547 qv with which it should be contemporary.

HAR-6561. S232

$3540 \pm 70$

$\delta^{13} C=-26.5 \%$

AML 841442, from satellite cremation grave F267 within area of barrow $\mathrm{B} 15$, but probably below barrow material. Comment (SCS): it is not known whether satellite cremation was buried at same time as funeral pyre or was placed between pyre phase and barrow construction. Date confirms that primary and satellite burials were broadly contemporary.

HAR-6566. S233

$3090 \pm 70$

$\delta^{13} C=-25.2 \%$

AML 841443, from cremation grave F272, in small cemetery of which other graves contained sherds of either Late Beaker or Early Bronze Age pottery.

\section{Cairn 38 series}

Charcoal samples from cairn site at Chysauster, CEU site 267, Carnaquidden Farm, Ludgvan, Cornwall $\left(50^{\circ} 9^{\prime} 50^{\prime \prime} \mathrm{N}, 5^{\circ} 32^{\prime} 25^{\prime \prime} \mathrm{W}\right.$, NGR: SW 472354). Coll by G H Smith and subm Feb 1985 by N Balaam.

\section{HAR-6548. 8410209}

$3650 \pm 80$

$\delta^{13} C=-25.2 \%$

Id. as Quercus sp by N D Balaam, AML 8410209, from top of old land surface sealed beneath cairn. Comment (GHS): charcoal was scattered over fairly wide area and was not just result of small fire but possibly of clearance of woodland prior to construction of cairn. Sample provides date for construction of kerb enclosure, which may have been ceremonial and which antedates insertion of first burials and building of cairn mound.

HAR-6549. 8410212

$$
\begin{array}{r}
3790 \pm \mathbf{1 2 0} \\
\delta^{13} C=-26.1 \% 0
\end{array}
$$

Id. as Quercus sp and Corylus avellana by N D Balaam, AML 8410212, from fill of pot containing cremation burial. Pot was contained in pit under small cist outside kerb of cairn.

HAR-6651. 8410213

$$
\begin{array}{r}
\mathbf{3 6 8 0} \pm \mathbf{8 0} \\
\delta^{13} C=-25.9 \% \text { o }
\end{array}
$$

Id. as Quercus sp by N D Balaam, AML 8410213, from fill of pot containing cremation burial, which was from pit outside kerb of cairn.

\section{Dubby Sike series}

Charcoal from complex site at Dubby Sike, Cowgreen Reservoir, Upper Teesdale, County Durham (54 $40^{\circ} 28^{\prime \prime} \mathrm{N}, 2^{\circ} 19^{\prime} 5^{\prime \prime} \mathrm{W}$, NGR: NY 
795311). Coll and subm Oct 1984 by D Coggins, The Bowes Mus, Barnard Castle.

HAR-6551. DS842P

$$
2110 \pm 90
$$

AML 843341, from small bowl-shaped pit in natural $\delta^{13} C=-26.2 \%$ cairn which covered flat stones.

HAR-6552. DS843GH

$$
\begin{array}{r}
2170 \pm 100 \\
\delta^{13} C=-26.4 \% o
\end{array}
$$

AML 843342, from beneath paving just outside entrance to large subcircular building at $\mathrm{S} W$ edge of site.

\section{Bawsey series}

Charcoal, id. as oak, from Mintlyn Wood, Bawsey, Norfolk $\left(52^{\circ} 45^{\prime} 0^{\prime \prime}\right.$ N, $0^{\circ} 27^{\prime} 56^{\prime \prime}$ E, NGR: TF 66381981). Coll and subm Nov 1984 by P Murphy.

HAR-6569. SML33

$$
\begin{array}{r}
\mathbf{3 5 6 0} \pm \mathbf{8 0} \\
\delta^{13} C=-26.7 \% 0
\end{array}
$$

AML 842808, from context 1304, secondary cremation inserted into mound of barrow with primary grave containing broken beaker and stain of bier. Comment (PM): sample assoc with pot and spoon-like artifact.

HAR-6614. SML17

$$
\begin{array}{r}
\mathbf{2 8 1 0} \pm \mathbf{8 0} \\
\delta^{13} C=-26.3 \% 0
\end{array}
$$

AML 842807, in deposit of burned flint, calcined bone, and pottery fragments, context 1002. Comment (PM): date interpreted as secondary cremation in mound of barrow with primary grave containing broken beaker and stain of bier.

\section{Sandon series}

Wood samples from valley sediments, in valley close to Neolithic cursus at Sandon Culvert, Springfield, Chelmsford, Essex $\left(51^{\circ} 42^{\prime} 41^{\prime \prime} \mathrm{N}, 0^{\circ} 31^{\prime}\right.$ 44" E, NGR: TL 747045). Coll and subm Nov 1984 by P Murphy.

HAR-6570. SANDTOP

AML 842811.

HAR-6580. SANDBASE

AML 842812. Comment (PM): sample provides date for base of pollen and macro-column samples from sec.

\section{Towcester Church series}

Wood, id. as Quercus sp, from two cores taken from head of effigy of Archdeacon Sponne at Towcester Church, Northamptonshire. Coll and subm July 1984 by D Haddon-Reece. 
HAR-6574. TOW1

AML 840108.

HAR-6575. TOW2

AML 840109.

$$
\delta^{13} C=-26.0 \%
$$

$$
\delta^{13} C=\begin{gathered}
\mathbf{2 4 0} \pm \mathbf{7 0} \\
-24.3 \% 0
\end{gathered}
$$

\section{Hullbridge series}

Samples taken from peat at sites on $\mathrm{N}$ bank of River Crouch opposite Hullbridge, Essex (52 31' 41" N, $0^{\circ} 39^{\prime} 24^{\prime \prime}$ E, Natl Grid Ref TL 802956). Coll June and subm July 1984 by P Murphy.

\section{HAR-6581. H52WOOD}

$$
\begin{array}{r}
1420 \pm 70 \\
\delta^{13} C=-27.7 \% 0
\end{array}
$$

Wood, AML 841420, from brushwood trackway in upper peat at Site 52. Comment (PM): trackway thought to be Late Roman or Early Saxon.

\section{HAR-6589. H4UPEATT}

$1380 \pm 80$

Peat, id. as Phragmites sp, AML 841421, from top 5cm of peat layer at Site 4. Comment (PM): sample provides date for top of upper peat, indicating change from freshwater to estuarine conditions (Murphy \& Wilkinson, 1982).

HAR-6604. STL7/43

$$
\begin{array}{r}
3990 \pm \mathbf{7 0} \\
\delta^{13} C=-24.6 \%
\end{array}
$$

Charcoal, id. as mostly oak, AML 841422 , from site 7, St Lawrence, Essex. Coll May 1984 and subm July 1984 by P Murphy, Centre for East Anglian Studies, Norwich. Comment (PM): sample probably relates to phase of forest clearance.

\section{HAR-6605. BRD0/83}

$$
\begin{array}{r}
1330 \pm \mathbf{8 0} \\
\delta^{13} C=-26.9 \%
\end{array}
$$

Charcoal, AML 841427, from 25 to $40 \mathrm{~cm}$ below Middle Saxon occupation layer, but above humified peat layer at Stanch Meadow, Brandon (BRD 018), Suffolk (52 26 46" N, $0^{\circ} 36^{\prime} 59^{\prime \prime}$ E, Natl Grid Ref TL 778864). Coll May 1984 and subm July 1984 by P Murphy. Comment (PM): sample appears to be related to clearance, by burning, of vegetation on site. Date defines beginning of site and is relevant to dating Ipswich Ware in general.

\section{Bradwell series}

Charcoal, id. as Quercus sp from beneath peat on head surface at site 8, Bradwell-on-Sea, Essex ( $51^{\circ} 44^{\prime} 36^{\prime \prime} \mathrm{N}, 00^{\circ} 53^{\prime} 50^{\prime \prime}$ E, Natl Grid Ref TM000090). Coll and subm July 1984 by P Murphy. 
HAR-6617. BRA8/32

$$
\begin{array}{r}
\mathbf{4 6 9 0} \pm \mathbf{7 0} \\
\delta^{13} C=-25.2 \% 0 \\
\mathbf{4 0 0 0} \pm \mathbf{7 0} \\
\delta^{13} C=-24.5 \% 0
\end{array}
$$

HAR-6618. BRA8/31

General Comment (PM): results provide date for Middle Neolithic site.

\section{Springfield series}

Charcoal from Late Bronze Age site at Springfield Lyons, Chelmsford, Essex (51 44' 46" N, $0^{\circ} 30^{\prime} 49^{\prime \prime} \mathrm{E}$, Natl Grid Ref TL 735083). Coll and subm Nov 1984 by P Murphy.

HAR-6621. SB3558

$3760 \pm 70$

Id. as oak, AML 842809, from pit. Comment (PM): result provides terminus post quem for enclosure.

HAR-6622. SB3666

$2830 \pm 70$

Id as oak, ash and hazel/aldr house.

$$
\delta^{13} C=-24.1 \% 0
$$

HAR-6623. MAY341 $\begin{array}{r}\mathbf{4 1 9 0} \pm \mathbf{8 0} \\ \delta^{13} C=-26.2 \%\end{array}$

Wood, id. as oak, AML 841423, from peat overlying head surface at site 3, Maylandsea, Essex (Natl Grid Ref 915046). Coll June and subm July 1984 by P Murphy.

\section{Sproatley series}

Two samples from series of bog oaks excavated in 1984 during drainage in Carr land at Sproatley, Humberside (Natl Grid Ref TA 205347). Samples coll and subm May 1985 by D Crowther, City of Kingston upon Hull, Museum and Art Gallery.

\section{HAR-6626. SPRTLY1A}

HAR-6627. SPRTLY1B

$$
\begin{array}{r}
\mathbf{6 3 1 0} \pm \mathbf{8 0} \\
\delta^{13} C=-25.6 \% 0 \\
\mathbf{6 3 0 0} \pm \mathbf{8 0} \\
\delta^{13} C=-26.1 \% 0
\end{array}
$$

General Comment: bog oaks were found in peat at depth ca $5 \mathrm{~m}$. One showed signs of having been chopped apart ca $2 \mathrm{~m}$ from root bole. How long after death that tree was chopped is not known, although angle of chopped surface and distance from root bole point to possibility of tree leaning in rising bog. ${ }^{14} \mathrm{C}$ results suggest Neolithic felling and toolmark studies are awaited.

\section{Bushmead Priory series}

Wood from Bushmead Priory, Eaton Socon, Bedfordshire (Natl Grid Ref TL 108108) (Hughes, Milson \& Leggett, 1981). Coll 1981 and subm May 1985 by D Haddon-Reece. 
HAR-6628. 16N1B

Id. as oak (Quercus sp) from rings 11 to 20 of 30 -year sequence of timber $16 \mathrm{~N} 1$.

HAR-6629. 16N1C

$$
\delta^{13} C=-25.4 \%
$$

Id. as oak (Quercus sp) from rings 1 to 10 of timber $16 \mathrm{~N} 1$.

\section{Davidstow Moor series}

Charcoal from separate barrows at Davidstow Moor, Cornwall. Coll 1941 and 1942 and subm Dec 1984 by P Christie, Inst Archaeol, London.

HAR-6634. DM147

$3520 \pm 70$

$\delta^{13} C=-25.2 \%$

Id. by C R Cartwright as including Corylus, Calluna, Quercus, Carpinus, Betulus, and Leguminosae spp, AML 851366, from fires 1 and 2 in Barrow 1 $\left(50^{\circ} 38^{\prime} 23^{\prime \prime} \mathrm{N}, 04^{\circ} 37^{\prime} 33^{\prime \prime} \mathrm{W}\right.$, Natl Grid Ref SX 14358560).

\section{HAR-6635. DM24}

$3580 \pm 70$

$$
\delta^{13} \mathrm{C}=-26.8 \%
$$

Id. by C R Cartwright as including Calluna, Quercus, and Leguminosae spp, AML 851364, from miniature cairn outside kerb on axis of SE quad of Barrow 2 (50 37 $54^{\prime \prime}$ N, $04^{\circ} 36^{\prime} 28^{\prime \prime}$ W, Natl Grid Ref SX 15608465). Comment (PMC): result relates satisfactorily to early collared urn tradition.

HAR-6640. DM82

$$
\begin{array}{r}
\mathbf{3 7 4 0} \pm \mathbf{9 0} \\
\delta^{13} C=-26.0^{0} \% 0
\end{array}
$$

Id. by C R Cartwright as including Calluna and Leguminosae spp, AML 851365 , from center of old turf in Barrow $8\left(50^{\circ} 38^{\prime} 21^{\prime \prime} \mathrm{N}, 04^{\circ} 37^{\prime} 20^{\prime \prime} \mathrm{W}\right.$, Natl Grid Ref SX 14608550).

\section{HAR-6643. DM223}

$$
\begin{array}{r}
4130 \pm 70 \\
\delta^{13} C=-25.6 \% 0
\end{array}
$$

Id. by C R Cartwright as including Corylus, Calluna, Quercus, Leguminosae, and Salix/Populus spp, AML 851367, from pit 16 in Barrow $22\left(50^{\circ} 38^{\prime}\right.$ $59^{\prime \prime} \mathrm{N}, 04^{\circ} 37^{\prime} 38^{\prime \prime} \mathrm{W}$, Natl Grid Ref SX 14308670). Comment (PMC): result is unsatisfactory as sample is believed to relate to pre-barrow (Grooved Ware) occupation of site.

General Comment (PMC): ${ }^{14} \mathrm{C}$ dating is sole way of dating barrows more precisely and establishing relationship between them. It is fortunate that charcoal was retained from 1940s excavations.

\section{Ham Hill series}

HAR-6653. 252/84

$2160 \pm 90$

Charcoal, id as Alnus sp, AML 8312852, from Iron Age pit at Ham Hill. Coll and subm April 1985 by N Balaam. 


\section{Greyhound Yard, Dorchester series}

Two antler samples, id. as Cervus elaphus L sp, from primary contexts of large Neolithic monument in SE corner of Roman town of Dorchester (Durnovaria), Greyhound Yard site $\left(50^{\circ} 42^{\prime} 49^{\prime \prime} \mathrm{N}, 2^{\circ} 26^{\prime} 4^{\prime \prime} \mathrm{W}\right.$, Natl Grid Ref: SY 69349060). Samples coll Aug and subm Nov 1984 by P J Woodward. For description of excavations, see Woodward, Davies and Graham (1984).

HAR-6663. W67.4947

$4020 \pm 80$

$\delta^{13} C=-23.8 \%$

Frontal bone and skull attached to antler from mature stag, AML 843338, from Late Neolithic post-pit.

HAR-6664. W67.4166

$4070 \pm 70$

$\delta^{13} C=-23.6 \%$

Base and shaft of mature shed antler, AML 843339, from post pipe. General Comment (PJW): two results are consistent with each other and also with HAR-5508 (4060 $\pm 90 \mathrm{BP})$ and provide date in late Neolithic slightly earlier than those of two neighboring sites, shafts at Mammbury Rings (BM$2281,3650 \pm 70$ and $-2282,3640 \pm 70)$ (Bradley $\&$ Thomas, 1985) and palisade at Mount Pleasant (Wainwright, 1979).

\section{Chelmer Bridge series}

Wood taken from detritus mud at Chelmer Bridge $\left(5143^{\prime} 48^{\prime \prime} \mathrm{N}, 0^{\circ} 31^{\prime}\right.$ 32" E, NGR: TL 74390655). Coll and subm May 1985 by P Murphy.

HAR-6682. CBBASE

AML 852732, from base of detritus mud.

HAR-6683. CBTOP

AML 852733, from top of detritus mud.

\section{Asheldham Camp series}

Charred grain samples, id. as wheat (Triticum sp), from Asheldham Camp, Essex (51 40' 28" N, $0^{\circ} 51^{\prime} 9^{\prime \prime}$ E, Natl Grid Ref TL 972012). Coll April 1985 by $\mathrm{O}$ Bedwin, Essex County Council and subm July 1985 by P Murphy. For report on site, see Essex County Council (1985).

HAR-6700. AC8563

AML 852765, from lower fill of pit 62 in trench F.

HAR-6701. AC8538

AML 852764, from fill of context 37.

$$
\begin{array}{r}
1980 \pm \mathbf{8 0} \\
\delta^{13} C=-24.4 \%
\end{array}
$$

$2190 \pm 70$

$\delta^{13} C=-24.8 \%$ 
HAR-6702. AC8534

AML 852763, from lower fill of pit 62 in trench $F$.

General Comment $(\mathrm{OB})$ : all samples were assoc with middle Iron Age pottery.

\title{
Dalton Parlours series
}

Two samples from series of six from occupation site at Dalton Parlours, Collingham Parish, Near Wetherby, West Yorkshire (53 53' 42" N, $1^{\circ} 23^{\prime} 18^{\prime \prime} \mathrm{W}$, Natl Grid Ref SE 402445). Site is multi-phase Iron Age occupation site of several acres and comprises a complex of linked irregular single-ditched enclosures within which were round houses and other typical Iron Age structures. After a break in occupation, a large Roman Villa existed and thereafter some Anglo-Saxon activity is suspected. All samples coll 1976 to 1978 by A B Sumpter and subm March 1985 by J D Hedges.

\section{HAR-6714. DP5005}

Human bone, AML 852634, from burial.

HAR-6716. DP0032

$$
\begin{array}{r}
\mathbf{1 7 8 0} \pm \mathbf{8 0} \\
\delta^{13} C=-20.7 \% 0
\end{array}
$$

$\mathbf{2 0 9 0} \pm \mathbf{8 0}$

Animal bone, AML 852636. Comment: $\delta^{13} \mathrm{C}$ value is assumed.

\section{Moss Mire series}

Peat from Moss Mire, Barnard Castle, Co Durham. Coll and subm Jan 1979 by A M Donaldson.

HAR-6804. MM220

$$
\begin{array}{r}
\mathbf{2 1 7 0} \pm \mathbf{1 1 0} \\
\delta^{13} C=-29.5 \%
\end{array}
$$

AML 790084, from forested period preceding first major clearance.

\section{HAR-6805. MM260}

$4720 \pm 130$

AML 790085, lowest datable sample from forested period preceding first major clearance.

\begin{abstract}
Aldwark series
HAR-6887. EBR5556

${ }^{13} \mathrm{680} \pm \mathbf{8 0}$

AML 777855, bone, fragmentary skull of man 25-35 years old, with widespread ulceration of external surface of both parietals and frontal bone, possibly from syphilis (Dawes \& Magilton, 1980). From context 1162, described as 'late medieval level,' NW (ie, on liturgical N side) of church of St Helen-on-the-Walls, Ebor Cemetery, Aldwark, York (53 $57^{\prime} 41^{\prime \prime} \mathrm{N}, 1^{\circ} 4^{\prime}$ 31" W, Natl Grid Ref SE 60665212). Coll April 1974 by J D Dawes and subm Aug 1977 by H K Kenward, York Archaeol Trust.
\end{abstract}




\section{REFERENCES}

Bradley, R and Thomas, J, 1985, Some new information on the henge monument at Mammbury Rings: Dorset Nat Hist Archaeol Soc Proc, v 106, p 132-135.

Dawes, J D and Magilton, J R, 1980, The cemetery of St Helen-on-the-Walls, Aldwark, in The Archaeol of York, v 12, pt 1, p 58, 98.

Essex County Council, 1985, Asheldham Camp. A report on the 1985 excavations, including recommendations for management of the monument: Chelmsford, Essex.

Fasham, P J, 1985, The prehistoric settlement at Winnall Down, Winchester: Hampshire Field Club mono 2.

Garton, D, 1983, Newton Cliffs, Lincolnshire/Nottinghamshire: Lincolnshire Hist and Archaeol, v 18, p 100-102.

Greenfield, E, 1956, Barrow 4, Swarkestone Lows: Derbyshire Archaeol Jour, v 76, p 34-39. 1960, The excavation of barrow 4 at Swarkestone, Derbyshire: Derbyshire Archaeol Jour, v 80, p $1-48$.

Hughes, M, Milsom, S J and Leggett, P A, 1981, Sapwood estimates in the interpretation of tree-ring dates: Jour Archaeol Sci, v 8, no. 4, p 381-390.

Murphy, P and Wilkinson, T J, 1982, The Hullbridge Basin Survey, No. 1: Essex Co Council, Chelmsford, Essex.

O'Hare, G B, 1985, Archaeology in the Somerset Levels: Somerset Levels Papers, v 11, p 6.

Olivier, A C H, 1983, Manor Farm, Borwick, Lancs: Bronze Age cairn: Prehist Soc Proc, v 49, p 389-392.

Orme, B J, Coles, J M, Caseldine, A E and Bailey, G N, 1981, Meare Village West 1979: Somerset Levels Papers, v 7, p 12-69.

Otlet, R L, 1977, Harwell radiocarbon measurements II: Radiocarbon, v 19, no. 3, p 400423.

1979, An assessment of errors in liquid scintillation methods of ${ }^{14} \mathrm{C}$ dating, in Berger, R and Suess, H E, eds, Radiocarbon dating, Internatl ${ }^{14} \mathrm{C}$ conf, 9 th, Proc: Berkeley, Univ California Press, p 256-267.

Otlet, R L, Huxtable, G, Evans, G V, Humphreys, D G, Short, T D and Conchie, S J, 1983 , Development and operation of the Harwell small counter facility for the measurement of ${ }^{14} \mathrm{C}$ in very small samples, in Stuiver, $\mathrm{M}$ and $\mathrm{Kra}, \mathrm{R} \mathrm{S}$, eds, Internatl ${ }^{14} \mathrm{C}$ conf, 11 th, Proc: Radiocarbon, v 25, no. 2, p 565-575

Otlet, R L, Huxtable, G and Sanderson, D C W, 1986, The development of practical systems for ${ }^{14} \mathrm{C}$ measurement in small samples using miniature counters, in Stuiver, $\mathrm{M}$ and $\mathrm{Kra}, \mathrm{R}$ S, eds, Internatl ${ }^{14} \mathrm{C}$ conf, 12 th, Proc: Radiocarbon, v 28, no. 2A, p 603-614.

Otlet, R L and Walker, A J, 1979, Harwell radiocarbon measurements III: Radiocarbon, v 21, no. 3, p 358-383.

Otlet, R L and Warchal, R M, 1978, Liquid scintillation counting of low-level ${ }^{14} \mathrm{C}$, in Crook, M A and Johnson, P, eds, Liquid scintillation counting: London, Heyden, v 5, p $210-$ 218

Posnansky, M, 1956, Swarkestone Lows: Derbyshire Archaeol Jour, v 76, p 123-139.

Rodwell, W J and Rodwell, K A, 1982, St Peter's Church, Barton-upon-Humber: Antiquity, v 62, p 283-315.

Stanford, S C, 1980, The archaeology of the Welsh marches: London, Collins.

1982, Bromfield, Shropshire-Neolithic, Beaker and Bronze Age sites, 1966-79: Prehist Soc Proc, v 48, p 279-320.

Wainwright, G, 1979, Mount Pleasant, Dorset; Excavations 1970-1971: Soc Antiquarian Research Repts, London.

Walker, A J, Keyzor, R S and Otlet, R L, 1987, Harwell radiocarbon measurements V: Radiocarbon, v 29, no. 1, p 78-99.

Whimster, R, 1977, Harlyn Bay: The excavations of 1900-1905 in the light of recent research: Cornish Archaeol, v 16, p 60-89.

Woods, H, 1987, Wenlock Priory: British Archaeol Assoc Jour, v 140, p 36-75.

Woodward, P J, Davies, S M and Graham, A H, 1984, Excavations on the Greyhound Yard Car Park, Dorchester, 1984: Dorset Nat Hist Archaeol Soc Proc, v 106, p 99-106.

Woodward, P J, 1988, The South Dorset Ridgeway survey and excavations 1977-1983: The pre-Iron Age landscapes: Dorset Nat Hist Archaeol Soc, mono ser, in press. 